\title{
Volatile Fatty Acids Production in the Rumen of Young Heifers Given Diets Containing a Large Proportion of Concentrate
}

\author{
Shuichi Oshio, Ichiro Tahata, Haruo Kobayashi \\ and Tsuyako AMI \\ Animal Science Division, National Grassland Research \\ Institute, Nishinasuno, Tochigi-ken 329-27
}

(Received February 21, 1977)

\begin{abstract}
The rate of production of volatile fatty acids (VFA) in the rumen of animals on high concentrate feeding was studied with eighteen young heifers fitted with a permanent rumen fistula, using a single injection method of ${ }^{14} \mathrm{C}$-acetate and polyethylene glycol (PEG) in order to get some basic informations of rumen fermentation on concentrate diets. The results obtained were as follows; 1) The $\mathrm{pH}$ value, total VFA concentration, and proportion of each acid on all-concentrate diets showed distinguished differences in comparison with those of the animals fed a large proportion of hay, but varied widely between days and heifers. 2) VFA proportions were significantly correlated with $\mathrm{pH}$. At the $\mathrm{pH}$ value of about 5.2, acetic acid was minimum, and propionic acid and valeric acid were maximum in molar proportion. 3) It was suggested that, in the case of all-concentrate feeding for a long period, the VFA production in the rumen was depressed to $33.5-41 \%$ of digestible energy. In the animals fed hay and concentrate, the percentage was about $50 \%$.
\end{abstract}

Abnormality of rumen fermentation and low growth rate have often been observed in heifers on common pasture during the early part of the grazing period. One of the causes is supposed to be the abrupt change from concentrate to herbage, since the feeding regime in Japan is commonly based on the diets containing a large proportion of concentrate. The studies about rumen fermentation of the animals fed the concentrated diets have often been reported with respect to VFA concentration and proportion of each acid ${ }^{1-103}$. However, the production of VFA in the rumen on all-concentrate diet has not been reported except one by WhIteLAw et al.11) on barley feeding with in vitro technique. As a part of studies of adaptative changes of rumen fermentation to various diets, this study was conducted to obtain some basic information about the VFA production in the rumen of heifers fed a concentrate alone.

\section{Experimental Procedure}

Animals and feeding regime: This study consisted of seven experiments, in which eighteen Holstein heifers equipped with rumen fistula were used. The number and weight of heifers and the diets used in each experiment were shown in Table 1. The heifers were kept in stanchions and offered the experimental diets at 9-10 AM and 4 PM in equal amounts daily. Water was availa. ble for them at all times in these experiments. The heifers used in Expt 1 had been fed hay and concentrate together for a month. The measurement of VFA production was carried out at 
Oshio, Tahata, Kobayashi and Ami

Table 1. Experimental design and diets used

\begin{tabular}{|c|c|c|c|c|}
\hline Exp. No. & $\begin{array}{l}\text { No. of } \\
\text { heifers }\end{array}$ & $\begin{array}{l}\text { Mean body } \\
\text { weight (kg) }\end{array}$ & & $\begin{array}{l}\text { /day } \\
\mathrm{kg})\end{array}$ \\
\hline 1 & 9 & 124 & $\begin{array}{c}\text { concentrate A } \\
\text { + hay }\end{array}$ & $\begin{array}{l}1.0 \\
1.5\end{array}$ \\
\hline 2 & 3 & 127 & concentrate $B$ & 4.0 \\
\hline 3 & 3 & 127 & 11 & 3.0 \\
\hline 4 & 2 & 136 & $" \prime$ & 3.0 \\
\hline 5 & 3 & 179 & $\prime \prime$ & 5.0 \\
\hline 6 & 3 & 97 & 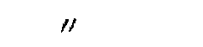 & 3.0 \\
\hline 7 & 3 & 98 & $\begin{array}{l}\prime \prime \\
+ \text { hay }\end{array}$ & $\begin{array}{l}2.0 \\
0.8\end{array}$ \\
\hline
\end{tabular}

the end of the period. Expts 2, 3, and 4 were conducted in series in order to investigate the adaptative change of rumen fermentation to a concentrate. The VFA production was measured on the 2nd, 5th, and 15th day after the commencement of feeding on the concentrate only. The animals in these experiments were three of the nine used in Expt 1. A heifer was removed from Expt 4 due to diarrhoea and anorexia. The heifers in Expt 5, which were not used in four previous experiments, had been fed the concentrate only for five weeks. VFA production was measured in the last week to investigate the stable condition of rumen fermentation on an all-concentrate diet. Expt 6 was carried out for the same objective as Expt 5. The VFA production was measured in the 6 th week of on all-concentrate feeding. The animals in Expt 7 had been fed hay and concentrate for five weeks and were sampled for VFA production in the last week. Digestibility trials were carried out in Expts 4, 5, 6, and 7 .

Feed constituents of experimental diets: The hay used in Expts 1 and 7 mainly consisted of orchard grass and partly white clover, Kentucky bluegrass, red top and meadow fescue.

Concentrate A consisted of $58 \%$ oats, $19.5 \%$ wheat bran, $19.5 \%$ soybean cake, $2 \%$ mineral mixture and 1\% sodium chloride. Concentrate B consisted of $30 \%$ milo, $20 \%$ barley, $20 \%$ corn, $10 \%$ rice bran, $10 \%$ defatted rice bran, $6.5 \%$ soybeen cake, $1.8 \%$ calcium carbonate, $1 \%$ sodium chloride, $0.5 \%$ calcium phosphate, $0.1 \%$ mineral mixture and $0.1 \%$ vitamine mixture. Chemical compositions of the concentrates were shown in Table 2.

Measurement of VFA production rate in the rumen: VFA production rate was measured with a single injection method of $\left[1-{ }^{14} \mathrm{C}\right]$ acetate and polyethylene glycol (PEG). Within an hour after feeding $200 \mathrm{ml}$ of very dilute solution, which included $40 \mathrm{~g}$ PEG (mol wt, 4000) and 10-15 $\mu \mathrm{Ci}$ sodium acetate ${ }^{1-14} \mathrm{C}$, was infused into the rumen via the fistula through a polyethylene pipe of

Table 2. Chemical composition of the concentrates

\begin{tabular}{lcccccc}
\hline & & \multicolumn{4}{c}{ based on dry matter $(\%)$} \\
\cline { 3 - 7 } & matter (\%) & $\begin{array}{l}\text { Crude } \\
\text { protein }\end{array}$ & $\begin{array}{c}\text { Crude } \\
\text { fiber }\end{array}$ & $\begin{array}{c}\text { Ether } \\
\text { extract }\end{array}$ & Ash & $\begin{array}{c}\text { Nitrogen } \\
\text { free } \\
\text { extract }\end{array}$ \\
\hline Concentrate A & 86.3 & 21.7 & 2.3 & 1.3 & 4.9 & 69.8 \\
Concentrate B & 87.4 & 15.2 & 5.8 & 1.5 & 6.9 & 70.6 \\
\hline
\end{tabular}




\section{VFA Production on Concentrate Feeding}

$2 \mathrm{~cm}$ internal diameter, mixing with the rumen fluid as homogeneously as possible. Samples of rumen fluid were drawn through the polyethylene tube of $3 \mathrm{~mm}$ internal diameter fixed to the rumen fistula, with the intraruminal end covered with a nylon net. This was done immediately before morning feeding and 6-11 times after feeding. The samples of rumen fluid were stored at $-20^{\circ} \mathrm{C}$ for analysis after measuring the $\mathrm{pH}$ values and mixing with mercuric chloride.

Analytical method: The $\mathrm{pH}$ values of rumen fluid were determined by glass electrode $\mathrm{pH}$ meter. After melting the stored samples, PEG concentration in a portion of rumen fluid sample was estimated by the method of HxDEN. ${ }^{12}$ The residual samples were centrifuged at $3000 \mathrm{rpm}$ for 15 minutes for the measurement of specific activity of ${ }^{14} \mathrm{C}-\mathrm{VFA}$ and VFA analysis in the rumen fluid. The specific activity of ${ }^{14} \mathrm{C}-\mathrm{VFA}$ in the rumen fluid was determined by liquid scintillation counting in a Packard Tricarb Liquid Scintillation Spectrometer Model 2003. The correction for quenching was made by using the external standardization. The scintillation mixture for radioactive counting comprised $7 \mathrm{~g}$ PPO (2,5-diphenyloxazole), $0.3 \mathrm{~g}$ POPOP [2,2-p-phenylenebis (5-phenyloxazole)] and $50 \mathrm{~g}$ naphthalene per a liter of dioxane. One $\mathrm{m} l$ of the supernatant of the sample was mixed with $10 \mathrm{~m} l$ of the scintillation mixture, centrifuged at $3000 \mathrm{rpm}$ for 10 minutes, and was measured for the specific activity. VFA concentration and proportion of acid were measured on a Shimadzu GC-5A gas chromatograph, using a $150 \mathrm{~cm}$ column packed with Diasolid S, 60-80 mesh and $20 \%$ ethylene glycol sebacate with nitrogen as the carrier gas and column temparature at $150^{\circ} \mathrm{C}$. One $\mathrm{m} l$ of rumen fluid sample was mixed and deproteinized with $0.2 \mathrm{~m} l$ of $20 \%$ metaphosphoric acid solution, the supernatant was used for VFA analysis by gas chromatography with crotonic acid as internal indicator. The concentrations of lactic acid and succinic acid in Expis 5,6 , and 7 were determined by gas chromatography with the same column as used for VFA analysis after being methylated with a boron trifluoride methanol complex. Malonic acid was used as the internal indicator.

Calculation of VFA production rate: The rate of production in the rumen, disappearance from the rumen, absorption from the rumen wall, and outflow to lower gut were calculated from the following equation;

$$
\frac{d x}{d t}=-\mathrm{K} x \text {, or } X=x_{0} e^{-\mathrm{K} t}
$$

$x$ represents the specific activity of ${ }^{14} \mathrm{C}-\mathrm{VFA}(\mathrm{dpm} / \mathrm{mmol}-\mathrm{VFA}$ for production rate, $\mathrm{dpm} / \mathrm{ml}$-rumen fluid for disappearance rate, or $\mathrm{dpm} / \mathrm{mg}$-PEG for absorption rate) or PEG for outflow rate at time t. $x_{0}$ represents the $x$ at the time of dosing. $\mathrm{K}$ is the constant rate that was calculated from the logarithmic regression of $x$ on time. Rumen fluid volume was estimated from the PEG concentration at the time of dosing. As the rate of VFA production considerably changed according to the time after feeding, the disappearance rate was used for the production rate,

\section{Results}

Table 3 shows pH, total VFA, and proportion of each acid of rumen fluid in each experiment in mean value. The $\mathrm{pH}$ values changed diurnally as shown in Fig. 1. When hay was fed together with concentrate, the $\mathrm{pH}$ values fluctuated as Expt 1 in Fig. 1 . In this case, the mean value was high and the range of variation was narrow. But, when the concentrate was fed, the patterns of the diurnal changes could be divided into two forms. One was a pattern shown in Expts 3 and 4 in Fig. 1. In such a pattern, the pH value was relatively high before feeding, but abruptly fell to a minimum in 2-4 hours after feeding, and then gradually rose until the next feeding. Expt 7, in which a small proportion of hay was given with a concentrate, also belonged 
Oshio, Tahata, Kobayashi and Ami

Table 3. Mean pII value, total VFA concentration and molar proportion of each acid on high concentrate feeding

\begin{tabular}{|c|c|c|c|c|c|c|c|c|c|}
\hline \multirow{2}{*}{$\begin{array}{l}\text { Exp. } \\
\text { No. }\end{array}$} & \multirow{2}{*}{$\begin{array}{c}\mathrm{pH} \\
\text { mean } \pm \mathrm{SD}\end{array}$} & \multirow{2}{*}{$\begin{array}{c}\text { Total VFA } \\
(\mathrm{mM})\end{array}$} & \multicolumn{7}{|c|}{ molar proportion of VFA (\%) } \\
\hline & & & Acet & Pro & Isobut & But & Isoval & Val & Cap \\
\hline 1 & $6.70 \pm 0.28$ & $93.4 \pm 23.1$ & 61.9 & 25.1 & 1.4 & 8.4 & 0.8 & 2.3 & 0.1 \\
\hline 2 & $5.65 \pm 0.54$ & $127.4 \pm 36.8$ & 51.4 & 28.5 & 1.4 & 12.7 & 1.5 & 4.0 & 0.5 \\
\hline 3 & $5.20 \pm 0.59$ & $167.3 \pm 43.2$ & 41.1 & 42.7 & 1.2 & 9.4 & 1.2 & 3.3 & 1.1 \\
\hline 4 & $5,33 \pm 0.67$ & $101.5 \pm 18.4$ & 42.4 & 33.9 & 1.6 & 12.5 & 1.1 & 8.0 & 0.5 \\
\hline 5 & $5.34 \pm 0.27$ & $141.1 \pm 24.8$ & 49.6 & 27.5 & 0.5 & 14.0 & 0.6 & 6.0 & 1.9 \\
\hline 6 & $5.07 \pm 0.69$ & $132.6 \pm 50.9$ & 52.3 & 28.4 & 0.6 & 12.4 & 0.5 & 4.1 & 1.7 \\
\hline 7 & $5.71 \pm 0.79$ & $141.6 \pm 56.1$ & 52.7 & 29.8 & 0.7 & 10.7 & 1.1 & 4.5 & 0.5 \\
\hline
\end{tabular}

to this pattern. The other was shown in Expts 2, 5 and 6 in Fig. 1. The pH values were relatively low even before feeding and fell in a small range after feeding. The diurnal fluctuation was relatively narrow. All of the mean daily $\mathrm{pH}$ values on all-concentrate feeding were below 6 in contrast to the high level of $\mathrm{pH}$ values in Expt 1 . The diurnal changes of VFA concentration were shown in Fig. 2. The concentration in Expt 1, which was the group given hay and concentrate, was lower and varied in a smaller range compared with the group fed the concentrate only. Though the VFA concentration on all-concentrate feeding was high, the fluctuation was not

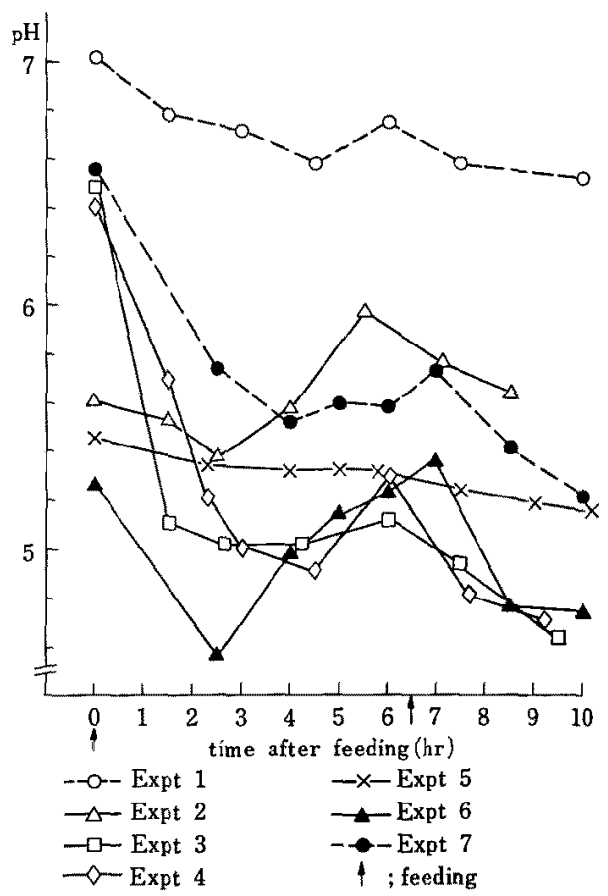

Fig. 1. The diurnal changes of $\mathrm{pH}$ in the rumen on high concentrate feeding

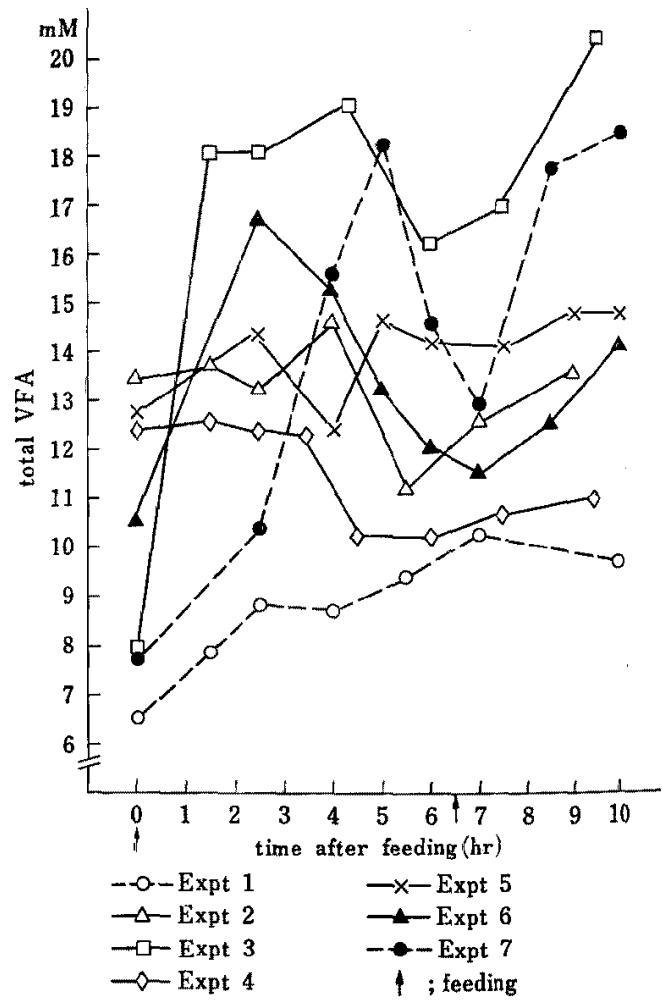

Fig. 2. The diurnal changes of total VFA on high concentrate feeding 
VFA Production on Concentrate Feeding

Table 4. A extreme difference between the heifers fed same concentrate diet in Expt 5

\begin{tabular}{|c|c|c|c|c|c|c|c|c|c|c|c|}
\hline \multirow{2}{*}{$\begin{array}{c}\text { amimal } \\
\text { No. }\end{array}$} & \multirow{2}{*}{$\mathrm{pH}$} & \multirow{2}{*}{$\begin{array}{l}\text { Total } \\
\text { VFA } \\
\text { (mM) }\end{array}$} & \multicolumn{7}{|c|}{ Molar proportion of VFA (\%) } & \multirow{2}{*}{$\begin{array}{l}\text { Lac- } \\
\text { tate }\end{array}$} & \multirow{2}{*}{$\begin{array}{l}\text { Suc- } \\
\text { cinate } \\
\text { (mM) }\end{array}$} \\
\hline & & & Acet & Pro & Isobut & But & Isoval & Val & Cap & & \\
\hline 50 & 5.41 & 116.8 & 41.1 & 18.7 & 0.5 & 25.5 & 0.8 & 10.7 & 2.7 & $\mathrm{NE}$ & 15.9 \\
\hline 45 & 5.21 & 159.6 & 45.4 & 42.3 & 0.6 & 6.7 & 0.5 & 4.1 & 0.3 & NE & $\mathrm{NE}$ \\
\hline
\end{tabular}

$\mathrm{NE}$; negligible

so wide except in Expts 3 and 6. But the concentration in Expt 7, that was the group given a small proportion of hay, changed at high level with wide fluctuation.

In the diurnal changes of VFA proportions, acetic acid, isobutyric acid, and isovaleric acid had a tendency to decrease after feeding. On the other hand, propionic acid increased after feeding. However, butyric acid, valeric acid, and caproic acid had no regular tendency. The mean daily proportions of each acid in these experiments were shown in Table 3 . Acetic acid was the lowest and propionic acid was the highest in molar proportion in Expt 3 that was on 5th day after the commencement of all-concentrate feeding. However, there were great differences in the proportion of each acid between days and the heifers on all-concentrate feeding. Table 4 showed a large difference in the proportions of VFA and succinic acid between heifers in Expt 5 . In No. 50 heifer, the proportion of propionic acid was very low. But the proportions of butyric acid, valeric acid, and caproic acid were very high. Succinic acid was also observed at high level in contrast with a trace of lactic acid, although both of succinic acid and lactic acid were negligible in other heifers in Expts 5, 6, and 7.

The relationships between $\mathrm{pH}$ and VFA proportions were shown in Fig. 3. The increase of
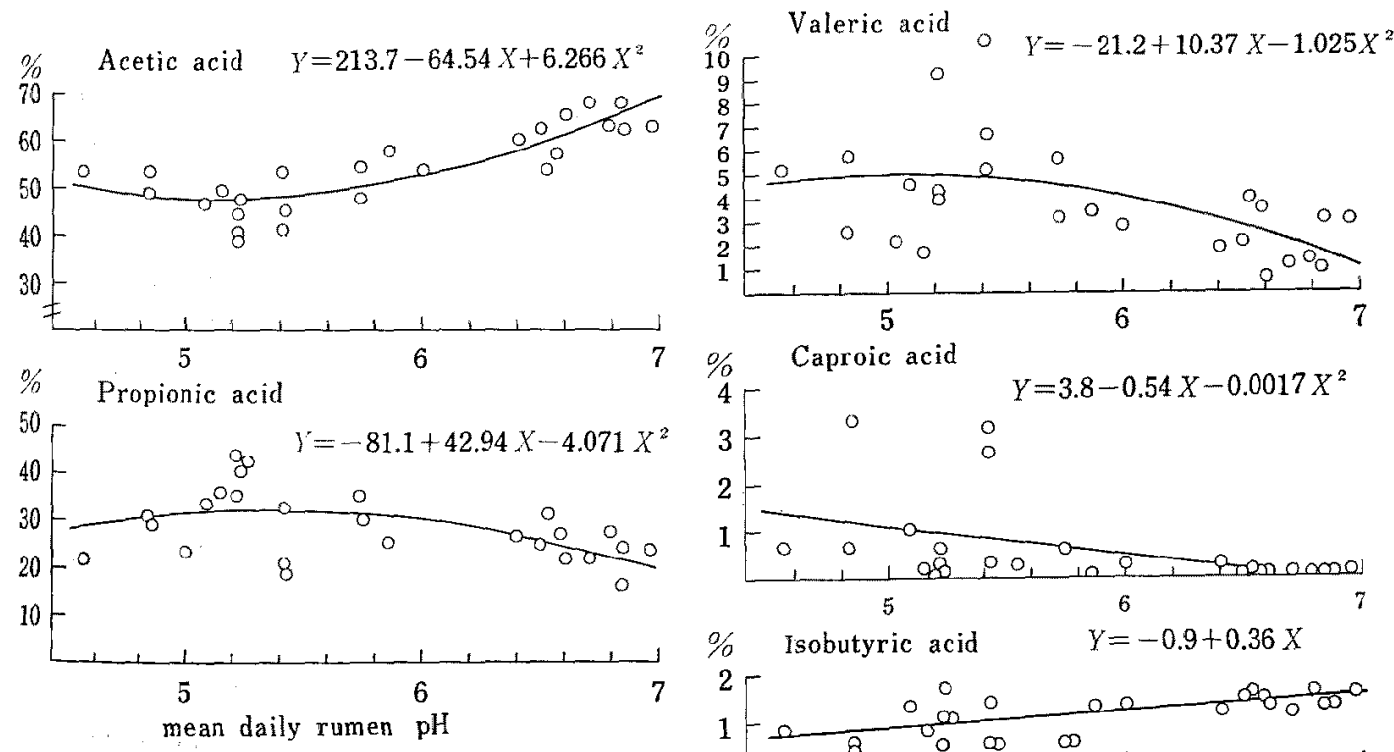

Butyric acid; non significant $(P>0.05)$. Isovaleric acid; non significant $(P>0.05)$.

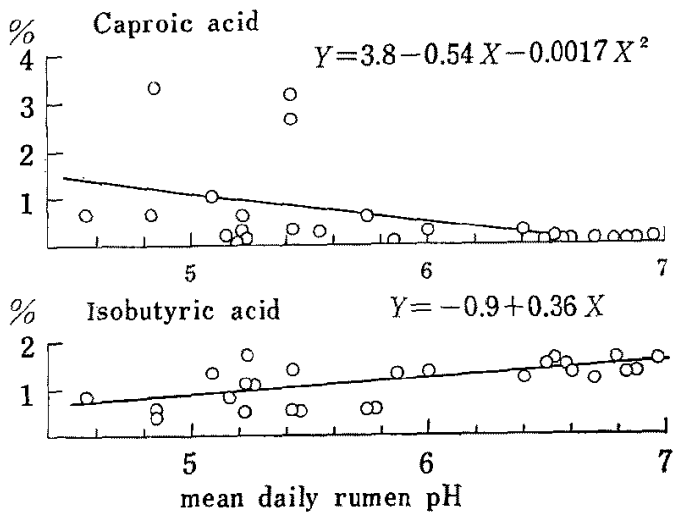

Fig. 3. The relationships between $\mathrm{pH}$ and VFA proportions on high concentrate feeding 
Oshro, TaHata, Kobayashi and Am!

Table 5. VFA production in the rumen on high concentrate feeding

\begin{tabular}{|c|c|c|c|c|c|c|}
\hline \multirow{2}{*}{$\begin{array}{l}\text { Exp. } \\
\text { No. }\end{array}$} & \multicolumn{3}{|c|}{ rate constant $(\% / \mathrm{hr})$} & \multirow{2}{*}{$\begin{array}{l}\text { produc- } \\
\text { tion rate } \\
\text { (mole } / \mathrm{hr} \text { ) }\end{array}$} & \multirow{2}{*}{$\begin{array}{l}\text { rumen } \\
\text { volume per } \\
100 \mathrm{~kg} \mathrm{wt} \\
\text { (i) }\end{array}$} & \multirow{2}{*}{$\begin{array}{c}\text { VFA/ } \\
\text { DE } \\
(\%)\end{array}$} \\
\hline & $\begin{array}{l}\text { out- } \\
\text { flow }\end{array}$ & $\begin{array}{l}\text { absorp- } \\
\text { tion }\end{array}$ & $\begin{array}{l}\text { produc- } \\
\text { tion }\end{array}$ & & & \\
\hline 1 & 13.1 & 22.8 & 35.8 & 424 & 10.9 & - \\
\hline 2 & 11.0 & 21.9 & 33.9 & 923 & 17.6 & 49.3 \\
\hline 3 & 10.0 & 27.2 & 37.2 & 848 & 10.7 & 63.0 \\
\hline 4 & 10.3 & 26.6 & 36.9 & 525 & 10.3 & 41.0 \\
\hline 5 & 7.7 & 21.6 & 29.3 & 696 & 9.4 & 38.0 \\
\hline 6 & 18.0 & 32.0 & 50.0 & 479 & 7.8 & 33.5 \\
\hline 7 & 13.1 & 19.6 & 32.7 & 564 & 13.2 & 49.8 \\
\hline
\end{tabular}

acetic acid and the decrease of propionic acid in molar proportion were observed at the $\mathrm{pH}$ value below about 5.2. At the mean daily $\mathrm{pH}$ value above about 5.2, propionic acid, valeric acid and caproic acid had significant tendencies to increase in molar proportion as $\mathrm{pH}$ value went down $(\mathrm{P}<0.01)$. On the other hand, acetic acid and isobutyric acid significantly decreased as $\mathrm{pH}$ value went down $(\mathrm{P}<0,01)$. Total VFA concentration was negatively correlated with $\mathrm{pH}(\mathrm{r}=-0.83$, $\mathrm{P}<0.01$ ) and the regression equation was expressed as follows;

$$
Y=380.2-44.1 X \quad Y=\mathrm{VFA} \text { concentration, } \mathrm{mM} \quad X=\mathrm{pH} \text { value }
$$

The rate constants of outflow, absorption, and production, production rate, rumen volume per $100 \mathrm{~kg}$ body weight and percentage of VFA in ingested digestible energy in each experiment were shown in Table 5. Outflow rate constant was $13 \% / \mathrm{hr}$ on an average in the heifers given hay and concentrate together. In the case of all-concentrate feeding, the mean daily outflow rate constants ranged from $4.1 \% / \mathrm{hr}$ to $18 \% / \mathrm{hr}$ among heifers. However, the mean value except Expt 6 was $9.7 \% / \mathrm{hr}$ that was significantly lower than those in the heifers fed on hay and concentrate diet in Expts 1 and 7. Absorption rate constants ranged from $21.6 \% / \mathrm{hr}$ to $32 \% / \mathrm{hr}$ among the animals on the concentrate diet only. In comparison with those on hay and concentrate diet that indicated $22 \% / \mathrm{hr}$ in mean value, the absorption rate constants had a higher value. The rumen volume on all-concentrate feeding except Expt 2 was $9.6 \mathrm{l}$ per $100 \mathrm{~kg}$ live weight on an average, and was significantly smaller than that on hay and concentrate feeding in these experiments $(P<0.05)$. The percentage of energy produced from VFA in ingested digestible energy in Expts 2 and 7 was about $50 \%$. The highest value, 63\%, was shown in Expt 3. However, the pecentage after third week after commencement of all-concentrate feeding decreased to below $41 \%$.

\section{Discussion}

It was observed in these experiments that, in the groups on all-concentrate feeding compared with those on hay concentrate feeding, $\mathrm{pH}$, and the proportions of acetic acid and isovaleric acid tended to be low, and the total VFA and proportions of propionic acid, valeric acid, and caproic acid were high. However, the proportion of individual VFA changed very widely in the groups on all-concentrate feeding. Though the reason why the great difference in the proportions of VFA between the heifers on the same concentrate and between days was not obvious, it seems to be attributable to the instability of the types and functions of microorganisms involved in rumen metabolism. These may have been changed by physiological condition of host animal or quan- 
tity of feed intake.

There were high positive correlations among the concentrations of butyric acid, valeric acid and caproic acid, particularly between butyric acid and valeric acid $(r=0.76)$. But the high correlations could not be easily explained because the metabolic pathways of valeric acid and caproic acid were not informed. However, it was considered that bacteria, such as Megasphaera elsderii ${ }^{13)}$ which produce higher acids from lactic acid, participated in the production of butyric acid, valeric acid and caproic acid. Furthermore, it is interesting that high concentration of succinic acid in contrast with a trace of lactic acid was detected in a heifer in Expt 5. In our knowledge, such a phenomenon has not been informed yet. In the same heifer, the proportion of propionic acid was much lower than those in other heifers in Expt 5. On that account, this may suggest that the metabolic pathway from succinic acid to propionic acid is sometimes inhibited during a long term feeding of a concentrate only though succinic acid was known as a important precursor of propionic acid ${ }^{14-16)}$.

The relationships between $\mathrm{pH}$ and VFA proportions were reported by several workers ${ }^{2,17-19}$. Also in these experiments, some significant relationships between $\mathrm{pH}$ and VFA proportions were observed. Rein et al. ${ }^{2}$ suggested the increase of acetic acid and the decrease of propionic acid in molar proportion at low $\mathrm{pH}$ level from the diurnal changes of $\mathrm{pH}$ and VFA proportions. Surton and JoHNSON${ }^{19)}$ also showed that such relationships were seen when the mean daily $\mathrm{pH}$ was $4.7-$ 5.1 with two cows on two rations. The present results also confirmed such phenomena. Although the proportion of butyric acid had a tendency to increase with large variation as $\mathrm{pH}$ fell, it may be affected more greatly by other factors than with $\mathrm{pH}$. The relationship between $\mathrm{pH}$ and valeric acid was similar to that between $\mathrm{pH}$ and propionic acid. The similarity may be caused by the same $\mathrm{pH}$ requirement of bacteria or of enzymes responsible for the production of propionic acid and valeric acid and interconversion between them. Though it was reported ${ }^{20-22)}$ that the concentration of caproic acid was fairly high in the rumen fluid on high concentrate diet, the relationship with $\mathrm{pH}$ has not been reported. The concentration of caproic acid had a significant negative correlation with $\mathrm{pH}$ in these experiments $(\mathrm{P}<0.01)$. It is generally accepted that fatty acids with branched chains are produced from decomposition of amino acid or protein. However, Orskov et al. ${ }^{21}$, and Pradhan and HemKeñ22) reported that isovaleric acid increased by the intra-ruminal infusion of ethanol. Therefore, the interpretation of the role of fatty acids with branched chains is difficult. The present result showed the relationships of the concentrations of isobutyric acid and isovaleric acid with $\mathrm{pH}$ were not significant $(P>0.05)$. On that account, the production of isobutyric and isovaleric acid seems not to be affected by $\mathrm{pH}$.

Outflow rate constants on all-concentrate feeding except in Expt 6 were significantly lower than those on hay and concentrate diet $(\mathrm{P}<0.01)$, and agreed with the result of BaUman et al. ${ }^{23)}$ that was $9.6 \pm 2.8 \% / \mathrm{hr}$ with the cows fed on a high grain, low fiber diet. However, the high outflow rate constant in Expt 6 was considered to be induced by underdeveloped small rumen volume. The production rate constants in the present experiments were above $29 \% / \mathrm{hr}$, higher than that of KNox et al. ${ }^{24)}$ with lactating cows, and lower than those by GRAY et al. ${ }^{25)}$ with sheep and by $D_{A V_{I} S^{26)}}$ with lactating cows on high grain diets. The rumen volume on all-concentrate feeding except Expt 2 was significantly smaller than that on hay and concentration feeding in these experiments. But the rumen volume in Expt 2 was much larger than those in other periods on all-concentrate feeding, which may have been caused by a sudden change to concentrate and also retention of diets fed up to two days before.

The relationship between VFA production rate and pool size in the rumen was reported by 
WESTON and HogaN 27$)$ who showed the correlation was 0.81 with sheep on dried ryegrass and forage oats. The relationship in the present experiments also indicated similar high correlation $(\mathrm{r}=0.81)$.

The adaptative changes of VFA production in the rumen to all-concentrate diet were noteworthy. The percentage of energy produced from VFA in ingested digestible energy was $49.8 \%$ in Expt 7, in which animals had been fed hay and concentrate, and $49.3 \%$ in Expt 2 on the 2nd day after commencement of all-concentrate feeding. These were little less than $54 \%$ by GraY et al..$^{28)}$ on lucerne hay and $52 \%$ by LENG et al. ${ }^{29)}$ on pasture. However, the VFA production in Expt 3 on the 5th day after commencement of all-concentrate feeding increased to $63 \%$ of digestible energy with parallel increase of VFA concentrations. The precentage decreased to $41 \%$ in Expt 4 and, furthermore, indicated lower values in Expts 5 and 6 measured in 5-6th week after starting all-concentrate feeding. The highest concentration of total VFA from the first week to the second week after commencement of all-concentrate feeding and the decline of total VFA concentration after that were observed also by BIGHam et al.30), TREMERE et al.31), and Sutron and Johnso ${ }^{19}$, who discussed the phenomena as adaptative changes. Though Bigham et al. ${ }^{30)}$ suggested that the decline of VFA level was likely to be due to one of two major factors, namely, decreased rates of production or increased disappearance rates of VFA out of the rumen. They could not determine which was more important from their results. However, from the present result, the decline of VFA level on a long term feeding of an all-concentrate diet could be explained by decreased rate of production because of decreased percentage of VFA in digestible energy. The measurement of the percentage of VFA in digestible energy on all-concentrate diet has been done only by Whitelaw et al. ${ }^{11}$ ' with cattle on barley feeding with in vitro technique. They showed $36.5 \%$ of digestible energy was produced as VFA but considered the low produc tion rate to be a discrepancy of technique. However, the percentage of VFA in digestible energy on a long term feeding of a concentrate alone in these experiments was significantly lower than those on a hay and concentrate diet.

\section{References}

1) Balch, D. H., and S. J. Rowland, Brit J Nutr 11: 288-298، 1957.

2) Reid, R. L., J.P. Hogan, and P. K. Briggs, Aust J Agric Res 8: 691-710. 1957.

3) Bath, I. H., and J.A. F. RooK, J Agric Sci 64: 67-75. 1965.

4) Thompson, J. T., N. W. Bradley, and C. O. Little, J Anim Sci 24: 1179-1183. 1965.

5) Ghorban, K. Z., K. L. Knox, and G. M. Ward, J Dairy Sci 49: 1515-1518, 1966.

6) Toprs, J.H., W. D. C. Reed, and R.C. Elliotr, J Agric Sci 66: 233-240. 1966.

7) McCullough, M.E., and W.W.S. Smart, J Dairy Sci 51: 385-391. 1968.

8) Sutron, J. D., Brit J Nutr 23: 567-583. 1969.

9) Franks, L. G., and J.R. Newson, J Anim Sci 35: 404-409. 1972.

10) Izumı, Y., Jap J Zootech Sci 46: 11-18. 1975.

11) Whitelaw, F.G., J. Hyldgaard, R.S. Reid, and M. G. Kay, Brit J Nutr 24: 179-194. 1970.

12) Hyden, S, LantbrHohdk Ann 22: 139-145. 1955.

13) Hungate, R.E., The Rumen and Its Microbes 84-85. Academic Press. N. Y. and London. 1966.

14) BaLDWiN, R. L., W. A. Wood, and R. S. EMery, J Bact 85: 1346-1349. 1963.

15) Blackburn, T.H., and R.E. Hungate, Appl Microbiol 11: 132-135. 1963.

16) Jayasuriya, G.C.N., and R. E. Hungate, Archs Biochem Biophys 82: 274-287. 1959. 
VFA Production on Concentrate Feeding

17) Dirksen, G., Physioiology of Digestion and Metabolism in the Ruminant 612-625. Oriel Press. N. Y. and London. 1970.

18) Eadre, J. M., P. N. Hobson, and S. O. Mann, Anim Prod 9: 247-250. 1967.

19) Sutton, J. D., and V. W. Johnson, J Agric Sci 73: 459-468. 1969.

20) Orskov, E. R., W. P. Flatt, P.W. Moe, and R. R. Oltjen, J Dairy Sci 50: 239-242. 1967.

21) Orskov, E. R., R. W. Hemken, and L. A. Moore, J Dairy Sci 50: 692-695. 1967,

22) Pradhan, K., and R. W. Hemken, J Dairy Sci 53: 1739-1746. 1970.

23) Bauman, D.E., C.L. Davis, R. A. Frolish, and D. S. Sachan, J Dairy Sci 54: 928-930. 1971.

24) Knox, K. L., A. L. Black, and M. Kleiber, J Dairy Sci 1716-1720. 1967.

25) Gray, F. V., G. B. Jones, and A. F. Pilgrim, Aust J Agric Res 11: 383-388. 1960.

26) Davis, D. L., J Dairy Sci 1621-1625. 1967.

27) Weston, R.H., and J. P. Hogan, Aust J Agric Res 19: 419-432. 1968.

28) Gray, F.V., R.A. Weller, A.F. Pilgrim, and G.B. Jones, Aust J Agric Res 18: 625-634. 1967.

29) Leng, R. A., J. I. Corbett, and D. J. Brett, Brit J Nutr 22: 57-68, 1968.

30) Bigham, M. L., W. R. McManus, and G. B. Enwards, Aust J Agric Res 24: 425-438. 1973.

31) Tremere, A. W., W. G. Merrill, and J. K. Loosli, J Dairy Sci 51: 1065-1072. 1968.

\title{
濃厚飼料多給時に㧍ける第一男内 VFA 生産について
}

\author{
押尾秀一一田烟一良・小林春雄・阿見僌子
}

農林省草地試験場家畜部，杯木県西那須野町 329-27

\footnotetext{
濃厚䝭料堂多給した䡞の第一罚内 VFA 生座について の知見は非常に少ないので，第一胃フィステルを装着し たホルスタイン種育成磪牛妾用い，ポリエチレン・グリ コールと ${ }^{14} \mathrm{C}$-酶酸ソーダの 1 回投与法により, 沶厚飼料 のタ，あるい活一部乾草を給与した境合の第一鼠内で生 産されるVFAについて測定を行った，1）濃厚玍司料の み給与した場合には，乾草を同時に与えた場合に比べ て, pH は著しく低下し，最低 4.5 劣した。 VFA 裖 度は日内変動が大きいが，最高 $200 \mathrm{mM}$ 以上の值壳示 し，VFA 組成は日間変動，個体差が大きく不安定であ
}

った，2） pH とVFA 組成との間以有意な関係が認め られ，pH が5.2〜5.4 付近で酢酸割合が最低になり，プ ロピオン酸，吉草酸割合は最高值を示した，カプロン酸 は $\mathrm{pH}$ が低下子るに良って增加する傾向にあったが，酪

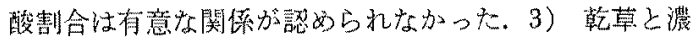
厚飼料を同時に与えた場合には，摂取された可消化エネ ルギーの約 50\%が第一胃内で VFA に変換されるのに 対し，濃厚飼料の学長期間給与した場合には，33.5〜 41\%に抑制されること肪示唆さ乹た。 